\title{
Working Capital Management Practices of Immigrant Entrepreneurs in South Africa
}

\author{
Olawale Fatoki \\ Department of Business Management, Turfloop Campus, \\ University of Limpopo, Limpopo Province, South Africa \\ Email: Olawale.fatoki@ul.ac.za
}

\section{Doi:10.5901/mjss.2014.v5n10p52}

\section{Abstract}

The study investigated the working management practices of immigrant entrepreneurs in South Africa. Effective working capital management is critical to the survival of firms. Data was collected through the use of self-administered questionnaire in a survey. Convenience sampling and the snowball sampling methods were used. Descriptive statistics was used for data analysis. The results showed that immigrant entrepreneurs on the average keep accounting books. The use of computer for operations is limited. Most of the respondents have bank accounts, do not bank their takings daily and do not prepare cash budgets. Most of the respondents buy and sell on credit. There is no written credit policy in place. Recommendations to improve the working capital management practices of immigrant entrepreneurs are suggested.

Keywords: working capital management practices, immigrant entrepreneurs, South Africa

\section{Introduction}

According to Pendleton et al. (2006), South Africa is a rainbow nation composed of various racial groups from all facets of the earth. Following independence in 1994, an increasing number of immigrants migrated to South Africa from other African countries and from other continents. Gibson et al. (2011) note that entrepreneurship can help to limit the persistently high unemployment rate generally associated with immigrants. Thus, immigrants can become a significant driving force in the creation of new businesses. Kalitanyi \& Visser (2010) and Gebre et al. (2011) point out that immigrant entrepreneurship can have positive impact on the South African economy. Most of the businesses owned by immigrants can be regarded as small and medium enterprises (SMEs). Researchers and policy makers often implicitly equate entrepreneurship with small business (Hurst \& Pugsley, 2010). South Africa suffers from high rate of unemployment with an official estimate of approximately $24.7 \%$ of the economically active population unemployed (Statistics South Africa, 2013). One of the best ways to address unemployment is to leverage the employment creation potential of SMEs (FinMark Trust, 2006). SMEs are expected to be an important vehicle to address the challenges of job creation, sustainable economic growth, equitable distribution of income and the overall stimulation of economic development in South Africa (Maas \& Herrington, 2006).

However, despite the noted contribution of SMEs (including immigrant-owned enterprises), it is estimated that the failure rate of SMEs in South Africa is between $70 \%$ and $80 \%$. As a result, many SMEs do not reach their full potential. This is a distinct and adverse feature of South Africa's entrepreneurial sector. Problems encountered by SMEs (including immigrant-owned enterprises) are numerous and can be described amongst others as being environmental, financial or managerial in nature (Brink et al. 2003). According to Tung and Aycan (2008), Petrus (2009) and Naqvi (2011) failure factors of SMEs include poor business and financial management competencies. Sound financial management is crucial to the survival and well-being of small enterprises of all types. One financial management practice that can impact on firm success is working capital management. Working capital management is considered to be a vital issue in a firm's overall financial management (Bagchi et al. 2012). The existence of an efficient and effective working capital management can make a substantial difference between the success and failure of an enterprise. Efficient management and financing of working capital can improve firm operating profitability (Agyei-Mensah, 2012). Working capital management is important because of its effects on a firm's profitability and risk, and consequently its value (Banos-Caballero et al. 2010), (Stephen and Elvis, 2011), (Akinlo, 2011). A review of the literature on immigrant entrepreneurship (Kalitanyi and Visser 2010), Tengeh et al. 2011) and working capital management (Erasmus, 2010), (Kwenda \& Holden 2013) revealed that no study has investigated empirically the working capital management practices of immigrant entrepreneurs in South Africa. 


\section{Objective of the Study}

Working capital management practices management can make a difference between the survival and failure of an enterprise. The objective of the study is to investigate the working capital management practices of immigrant entrepreneurs in South Africa.

\section{Literature Review}

Padachi et al. (2008) assert that the need for maintaining adequate working capital can hardly be questioned. Just as circulation of blood is very necessary in the human body to maintain life, the flow of funds is very necessary to maintain a business. Timmons \& Spinelli (2007) point out that cash flow and cash are the king and queen of entrepreneurial finance. According to Firer et al. (2004) working capital refers to a firm's short-term assets and liabilities. Short-term assets include cash, inventory, debtors and prepayments and short-term liabilities include overdrafts, accounts payable and accruals. Net working capital is the difference between firms' current assets and current liabilities. Working capital is required for the day-to-day running of a business. Working capital is needed to pay wages, suppliers, and other expenses before sale revenues are received from customers. Positive working capital means that the company is able to pay off its short-term liabilities. Negative working capital means that a company currently is unable to meet its short-term liabilities with its current assets. Therefore, the failure to plan for increasing working capital needs can lead to serious cash flow problems (Zaryawati et al. 2009). According to Arshad and Gondal (2013), there are two major concepts of working capital. These are gross working capital and net working capital. Gross working capital is referred as working capital and it include the total current assets of the firms. Net working capital is the difference between current assets and current liabilities of a trade and financial nature. Fatoki (2013) points out that working capital management involves managing the short-term assets and liabilities of a firm. Working capital management ensures that a firm has sufficient cash flow in order to meet its short-term debt obligations and operating expenses.

The management of working capital is one of the most important aspects of the overall financial management practices of any organization. Efficient management of working capital is an important indicator of sound health of an organisation. A firm is required to maintain a balance between profitability while conducting its day to day operations. While inadequate amount of working capital impairs a firm's liquidity, holding of excess working capital results in the reduction of the profitability (Ghosh \& Maji, 2004). Empirical studies generally find a positive relationship between the availability of working capital and firm success. Garcial-Teruel \& Martinez-Solano (2007) point out that non-availability of working capital is a major constraint to the survival and growth of SMEs. A large number of SME failures can be attributed to a lack of working capital. The success of a firm depends ultimately on its ability to generate cash receipts in excess of disbursements. According to Amrehein \& Katz (2000), the degree of a company's liquidity provides a critical measure of its mortality risk. Even if a firm is profitable, it still takes cash to pay the bills. Properly managing the area of working capital and cash flows is essential to the survival and growth of a business. This is particularly true of SMEs, which experience different circumstances than large firms including fewer available resources. Cash is also needed to maintain survival and sustain growth. As growth increases, an entrepreneurial firm's need for cash intensifies. Even if a business is enjoying success in other areas, a shortage of cash can result in technical insolvency, which will lead to bankruptcy and possible liquidation. These conclusions are consistent with the findings of other empirical studies. Song et al. (2008) find that the availability of working capital is one of the critical success factors for SMEs. Studies such as Padachi (2006) and Abuzayed (2012) find a positive relationship between the availability of working capital and firm performance. The efficient management of working capital is a fundamental part of the overall corporate strategy to create value for shareholders (Deloof, 2003), (Mohamad \& Saad, 2010).

\section{Research Methodology}

The survey was conducted in the Johannesburg Central Business District in Gauteng province of South Africa. The area is suitable for research because it has a high concentration of immigrant entrepreneurs. The empirical approach consists of data collection through the use of self-administered questionnaire in as survey. Because of the difficulty of obtaining the population of immigrant-owned businesses in the study area, convenience sampling and the snowball sampling methods were used. The questionnaires were given to the owners of the business to complete. The study centred on businesses in the retail sector. A pilot study was conducted on the survey instrument used in this research with 12 immigrant entrepreneurs in order to ensure face and content validity. The pilot study led to some modifications to the questionnaire. Owners were assured of confidentiality with regard to the data collected. Descriptive statistics was used for data analysis. 


\section{Results and Discussions}

120 questionnaires were distributed and 49 returned. The response rate was $40.8 \%$. Most of the respondents are males, with post-matric qualifications, in the 31-40 age bracket.

\subsection{Accounting information that can aid working capital management}

Table 1: Accounting information

\begin{tabular}{|l|c|c|}
\hline Accounting books & Yes & No \\
\hline Do you keep a stock book? & 29 & 20 \\
\hline Do you keep a cash book? & 31 & 18 \\
\hline Do you have a debtors' book? & 29 & 20 \\
\hline Do you keep a creditors' book? & 29 & 20 \\
\hline Do you use computer for your operations? & 19 & 30 \\
\hline
\end{tabular}

Table 1 depicts the use of accounting information that can aid working capital management by immigrant entrepreneurs. The results indicate that most of the respondents keep stock, books, cash books, debtors' books and creditors' books. However, most of the respondents do not use computer for their operations. The results indicate that the use of computer by immigrant entrepreneurs is very limited as those that keep books still use the manual method. Amidu et al. (2011) find that the use of computers by SMEs has the tendency to reduce cost, enhance clerical works, and provide sufficient space to store data and process information for management decision in a timely manner.

\subsection{Working capital practices}

Table 2: Working capital management practices

\begin{tabular}{|l|c|c|}
\hline Working capital management & Yes & No \\
\hline Do you have a bank account? & 47 & 2 \\
\hline Do you have a bank account specifically for your business? & 24 & 23 \\
\hline Do you bank your takings on a daily basis? & 17 & 30 \\
\hline Do you invest the cash balance in your account? & 3 & 44 \\
\hline Do you prepare a cash budget? & 1 & 48 \\
\hline Do you sell on credit? & 44 & 5 \\
\hline Do you have a credit policy in place? & 11 & 38 \\
\hline Do you have a specific number of days that you give your creditors to repay? & 19 & 30 \\
\hline Do you do credit check from a credit rating agency before selling on credit? & 0 & 49 \\
\hline Do you purchase on credit? & 44 & 5 \\
\hline Do you have a specific number of days that you use to pay your debt? & 17 & 32 \\
\hline
\end{tabular}

The results of working capital practices as depicted by table 2 indicate that most of the respondents have bank accounts. 24 respondents have bank accounts specifically for their business, while 23 respondents use their personal accounts for business. The lack of business account may impact negatively on the availability of bank loans to immigrant entrepreneurs. The majority of the respondents do not bank their takings on a daily basis. This may negatively impact on access to loans by immigrant entrepreneurs as commercial banks will not have an accurate assessment of their businesses. Most of the respondents do not invest the balance in their accounts. Investments even for a short-term period can add value to a business. Abanis et al. (2013) find that only a few SMEs that have cash surplus, do invest in marketable securities in order to generate more income. This practice hinders their growth and eventually leads to their failure. Most of the respondents do not prepare cash budgets. Cash flow management is the nucleus of a business for short and long-term survival. Uwonda et al. (2013) find that failures in many SMEs can be linked to inadequate cash flow management. The majority of SMEs do not prepare cash budgets. Most of the respondents sell and purchase on credit. Berger and Udell (2006) note that trade credit provides a cushion during credit crunches, monetary policy contractions or other shocks that leave financial institutions less willing or less able to provide small business finance. Since only a limited number of SMEs (including those owned by immigrants) have access to loans from financial institutions, trade credit may often be the best or only available source of external funding for working capital. Trade credit is a substitute to 
bank credit for firms that are credit-rationed by banks. According to Huyghebaert et al. (2007), trade credit in economic environments with weak informational infrastructure and less developed banking systems can play an even more important role in SME financing because of its strength in addressing the information problem.

Most of the respondents do not have a credit policy in place. This may lead high levels of bad debt. Abanis et al. (2013) note that the lack of credit policy implies that sales are made to customers without vetting who should be granted credit and how much credit should be granted. This makes recovery of the money from credit sales difficult. Most of the respondents do not have a specific number of days that are given to debtors to pay and none of the respondents does credit check before extending credit. Ashbaugh et al. (2004) find that credit history information provided by credit rating agencies is one of the determinants of the credit worthiness of a firm.

Table 3: Stock review

\begin{tabular}{|l|c|}
\hline & Yes \\
\hline Daily & 9 \\
\hline Weekly & 28 \\
\hline Monthly & 12 \\
\hline Do not review stock & 0 \\
\hline
\end{tabular}

Table 4: Restocking

\begin{tabular}{|l|c|}
\hline & Yes \\
\hline Stock is down & 32 \\
\hline periodically & 12 \\
\hline Consumer demand & 4 \\
\hline Projected sales & 1 \\
\hline Economic order quantity & 0 \\
\hline
\end{tabular}

Table 5: Insurance against fire and theft

\begin{tabular}{|c|c|}
\hline Yes & No \\
\hline 11 & 38 \\
\hline
\end{tabular}

Table 3 presents the results on how often immigrant entrepreneurs do stock review. Tables 4 and 5 depict the results of how immigrant entrepreneurs restock goods and whether they have insurance in place against fire and theft. The results reveal that most of the respondents review their stock on a weekly basis and restocking is mainly done when stock is down. Most of the respondents do not have insurance in place for fire and theft. Chidokufa (2009) finds that less than half of all South African SMEs have any insurance cover in place. Abanis et al. (2013) point out the lack of insurance cover implies that there is a low safeguard of inventory against fire and theft.

\section{Conclusions}

Immigrant entrepreneurs are a significant driving force in the creation of SMEs in South Africa. The failure rate of SMEs in general is very high in South Africa. The existence of an efficient and effective working capital management can make a substantial difference between the success and failure of an enterprise. The objective of the study was to investigate the working capital management practices of immigrant entrepreneurs in South Africa. The results showed that immigrant entrepreneurs on the average keep accounting books. The use of computer for operations is limited. Most of the respondents have bank accounts and buy and sell goods on credit.. The majority of the respondents do not bank their takings on a daily basis. Most of the respondents do not prepare cash budgets. There is no credit policy in place. Most of the respondents review their stock on a weekly basis and restocking is mainly done when stock is down. Most of the respondents do not have insurance covers in place against fire and theft.

\section{Recommendations}

Immigrant entrepreneurs need to take greater responsibility for their own learning. They can attend training programs 
organised by universities on financial management for non-financial managers and training programs organised by government agencies such as the Small Enterprise Development Agency (SEDA). Organisations responsible for small business development in South Africa should make conscious effort to recognise immigrant entrepreneurs as a specific target market for training. These organisations should have well trained field agents to visit and train immigrant entrepreneurs on a regular basis on how to keep books of accounts In addition, immigrant entrepreneurs need to move from manual to computers for record keeping. Immigrant entrepreneurs need to purchase computers and go for training on e-accounting. Universities (especially the management department) should make it part of their community engagement to visit immigrant entrepreneurs and train the owners on how to keep books of account.

\section{References}

Abanis, T., Sunday, A., Burani., A., \& Eliabu B. (2013). Financial Management Practices In Small And Medium Enterprises in Selected Districts In Western Uganda. Research Journal of Finance and Accounting, 4(2): 29-42.

Abuzayed, B (2012). Working capital management and firms' performance in emerging markets: the case of Jordan. International Journal of Managerial Finance, 8(2): 155-179

Akinlo, O. O. (2011). The effect of working capital on profitability of firms in Nigeria: Evidence from general method of moments (GMM).Asian Journal of Business and Management Sciences, 1(2), 130-135.

Agyei-Mensah, B.K (2012). Working Capital Management Practices of small Firms in the Ashanti Region of Ghana. International Journal of Academic Research in Business and Social Sciences, 2(1): 567-583.

Amidu, M., Effah, J., Abor, J (2011). E-accounting practices among small and medium enterprises in Ghana. Journal of Management Policy and Practice, 12(4): 147-155.

Amrehein., A, \& Katz, J.A (2000). Advances in study of entrepreneurship firm emergence and growth. Greenwich: Cincinnati JAI press.

Arshad, Z., \& Gondal M (2013). Impact of working capital management on profitability a case of the Pakistan cement industry. Interdisciplinary Journal of Contemporary Research in Business, 5(2): 384-390.

Ashbaugh, Hollis, Collins, Daniel, LaFond, Ryan. (2004). The Effects of Corporate Governance on Firms' Credit Ratings. [Online] Available: http://www.bus.umich.edu/JAE/Collins.pdf (February 7, 2014)

Bagchi, B., Chakrabarti, J., \& Roy P.B. (2012). Influence of Working Capital Management on Profitability: A Study on Indian FMCG Companies. International Journal of Business and Management, 7(22): 1-10.

Baños-Caballero, S., García-Truel, P.J., Martínez-Solano P. (2010). Working Capital Management in SMEs. Accounting \& Finance, 50: $511-527$

Berger, A., \& Udell, G (2006). A more conceptual framework for SME financing. Journal of Banking and Finance, 30(11): 2945-2966.

Brink A, Cant M, Ligthelm A 2003. Problems Experienced By Small Businesses in South Africa. [Online] Available: http://www.cecc.com.au/programs/resource-manager/ accounts/seaanz-papers/newdocant.pdf> (February 5, 2014)

Chidokufa, M. (2009). An investigation into the usage of insurance by SMEs in the Buffalo City Municipality. Unpublished Masters thesis, University of Fort Hare, South Africa.

Deloof, M. (2003). Does Working Capital Management Affect Profitability of Belgian Firms? Journal of Business Finance \& Accounting, 30 (3): 573-587.

Erasmus, P.D (2010). The relationship between working capital management and profitability for South African listed industrial firms. The Business Review, Cambridge, 15(1): 193-198.

Fatoki, O.O (2012). An Investigation into the Financial Management Practices of New Micro-enterprises in South Africa. Journal of Social Science, 33(2): 179-188.

FinMark Trust (2006). Fin Scope Small Business Survey Report. [Online] Available: http://www.finmarktrust.org.za (November 16, 2013).

Firer, C., Ross, S.A., Westerfield, R.W \& Jordan B.D. (2004). Fundamental of corporate finance South African Edition, (2nd ed.). Cape Town: McGraw Hill.

Garcial-Teruel, P.J., \& Martinez-Solano, P (2007). Effects of working capital management on SME profitability. International Journal of Managerial Finance, 3(2): 164-177.

Gebre, LT., Maharaj, P., \& Pillay N.K (2011). The experiences of immigrants in South Africa: A case study of Ethiopians in Durban, South Africa. Urban Forum, 22: 23-35.

Ghosh, S.K., \& Maji S.G (2004). Working capital management efficiency: a study on the Indian cement industry. The Management Accountant, 363-372.

Gibson, S.G., Harris, M.L., \& Sadighiam F (2011). Investigating the entrepreneurial attitudes of Armenian immigrants. Coastal Business Journal, 10(1): 1-13.

Huyghebaert, N., Van de Gucht, L. \& Van de Hulle C (2007). The choice between bank debt and trade credit in business start-ups. Small Business Economics, 2(9): 435-452.

Hurst, Erik, Pugsley, Benjamin (2010). Non Pecuniary Benefits of Small Business Ownership. [Online] Available: http://economics.stanford.edu/files/Hurstpp2_10_25.pdf (February 16, 2014).

Kalitanyi, V., \& Visser, K (2010). African immigrants in South Africa: Job takers or creators? South African Journal of Economics and Management Sciences, 13(4): 376-390.

Kwenda, F., \& Holden M (2013). Working Capital Structure and Financing Pattern of Selected JSE-Listed Firms. Mediterranean Journal 
of Social Sciences, 4(13): 531-540

Maas G., \& Herrington M (2006). Global Entrepreneurship Monitor South African Report. [Online] Available: http:/l www.gemconsortium.org/document.aspx?id756> (February 6 2012).

Mohamad, N.E.A.B., \& Saad N.B.M (2010). Working Capital Management: The Effect of Market Valuation and Profitability in Malaysia. International Journal of Business and Management, 5(11), 140-147.

Naqvi, S.W.H (2011). Critical success and failure factors of entrepreneurial organizations: Study of SMEs in Bahawalpur. Journal of Public Administration and Governance, 1(2): 17-22.

Padachi, K. (2006). Trends in Working Capital Management and its Impact on Firm"s Performance: An Analysis of Mauritian Small Manufacturing Firms. International Review of Business Research, 2(2): 45-58.

Padachi, K., Narasimhan, M.S., Durbarry, R \&Howorth, C. (2008). An analysis of working capital structure and financing pattern of Mauritian small manufacturing firms. Journal of Applied Finance, 14(7): 41-62.

Pendleton, Wade, Crush, Jonathan, Campbell, Eugene, Green, Thuso, Simelane, Hamilton, Tevera, Daniel, De Vletter, Fion (2006). Migration, Remittances and Development in Southern Africa. [Online] Available http://www.africaportal.org/dspace/ articles/migration-remittances-and-developmentsouthern- africa> (October 19, 2013).

Petrus, H.G (2009). An Investigation into Causes of Success and Failure in Small Businesses within the Department of Social Development in the Eastern Cape. Unpublished Masters' Thesis. Grahamstown: Rhodes University.

Song, M., Padoynitsyna, K., Vander, A., Bij, H. \& Halman J.I.M. (2008). Success factors in new ventures: a meta-analysis. Journal of Product Innovation Management, 25(1): 7-27.

Statistics South Africa 2013. Quarterly Labour Force Survey From <http://www.statssa.gov.za/publication/find publication asp> (Retrieved on October 29, 2013).

Stephen, M., \& Elvis K (2011), Influence of working capital management on firms profitability: a case study of SMEs in Kenya. International Business Management, 5(1): 279-286.

Tengeh, R.K., Ballard, H., \& Slabbert A (2012). Do immigrant towned businesses grow financially? An empirical study of African immigrant-owned businesses in Cape Town Metropolitan Area of South Africa. African Journal of Business Management, 6(19): 6070-6081.

Timmons, J.A. \& Spinelli, S. (2007). New venture creation: entrepreneurship for the $21^{\text {st }}$ century. (5 $5^{\text {th }}$ ed.). Boston: McGraw Hill

Tung, R.L., Aycan Z (2008). Key success factors and indigenous management practices in SMEs in emerging economies. Journal of World Business, 43(4): 381- 384.

Uwonda, G., Okello, N., \& Okello G (2013). Cash flow management utilization by Small Medium Enterprises (SMEs) in Northern Uganda. Merit Research Journal of Accounting, Auditing, Economics and Finance, 1(5): 67-80.

Zaryawati, M.A., Annuar, M.N., \& Abdul Rahim A.S (2009). Working capital management and corporate performance: case of Malaysia. Journal of modern accounting and auditing, 5(11): 47-54. 